\title{
Article
}

\section{What is the Point of Studying Childhood as a Social Phenomenon?}

Thomas, Nigel Patrick

Available at http://clok.uclan.ac.uk/26033/

Thomas, Nigel Patrick ORCID: 0000-0002-5310-9144 (2019) What is the Point of Studying Childhood as a Social Phenomenon? Children \& Society, 33 (4). pp. 324-332. ISSN 0951-0605

It is advisable to refer to the publisher's version if you intend to cite from the work. http://dx.doi.org/10.1111/chso.12297

For more information about UCLan's research in this area go to

http://www.uclan.ac.uk/researchgroups/ and search for <name of research Group>.

For information about Research generally at UCLan please go to http://www.uclan.ac.uk/research/

All outputs in CLoK are protected by Intellectual Property Rights law, including Copyright law. Copyright, IPR and Moral Rights for the works on this site are retained by the individual authors and/or other copyright owners. Terms and conditions for use of this material are defined in the policies page.

\section{CLoK}

Central Lancashire online Knowledge www.clok.uclan.ac.uk

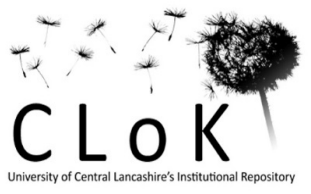




\section{What is the point of studying childhood as a social phenomenon?}

\section{Nigel Thomas}

\section{Introduction}

The problem which this paper seeks to address centres on three separate questions: Why focus on the social? Why focus on childhood? Why focus on those things now, at this point in history? The paper begins by explaining why these are critical questions for childhood studies, particularly in the light of contemporary developments in other fields. The latter include materialist and post-humanist turns in the social sciences, as well as a number of existential threats currently faced by humanity, which are arguably so urgent that time should not be wated on other issues. The paper then offers some reflections on the meaning and purpose of social inquiry and its relevance for childhood, which in their turn form the basis for a suggested response to the initial three questions and a fresh justification for doing what we do, but in a way that takes account of the critical issues raised.

\section{Why focus on the social?}

To focus on the social is to assume that we can tell a full and coherent story based on human social interaction. This implies (i) neglect of the biological dimension, (ii) neglect of the mechanical and technological, (iii) neglect of the non-human animal and (iv) neglect of the 'natural' world. Let us consider each in turn.

To neglect the biological dimension is to turn aside from the perception that we are embodied, and that our embodiment gives us our place in the world and our means of interacting. It is to ignore the importance of our individual genetic heritage, of the organic drivers and constraints on growth and development. To try to understand childhood or children's lives without reference to all this is to miss large and important parts of the picture. Insights from biology, neurology and indeed developmental psychology, once consigned to the 'dustbin of history' (James et al., 1998) all have their place in understanding childhood (see Woodhead, 2009).

To neglect the mechanical and technological is to ignore how (throughout human history, but perhaps now more than ever) we interact with tools and machines, the ways in which they affect how we experience the world and what we can do with it. Theories of 'assemblages' (DeLanda, 2006) and 'actor-network' (Latour, 2005) have been developed in an endeavour to understand these relationships more creatively. The impacts of domestic, industrial, military and communications technology, of computer hardware and software, the growth of artificial intelligence which raises the question whether machines are becoming social and whether they have intention - these must change how we understand our place in the world. 
To neglect the non-human animal is to fail to face the challenges being set for us by 'post-human studies', with their demand for us to recognise the agency of non-human animals and the complex ways in which humans relate to them. Such studies aim to 'decentre the human as the sole learning subject and explore the possibilities of interspecies learning... paying close attention to our mortal entanglements and vulnerabilities with other species, no matter how small, can help us to learn with other species and rethink our place in the world' (Taylor and Pacini-Ketchabaw, 2015).

To neglect the 'natural' world more generally is to miss all the complex ways in which humans (and other species) are intertwined with the physical environment, in which people shape, and are shaped by, the material world, from the impacts of agriculture and husbandry, forestation and deforestation, mining and smelting to the now widely recognised advent of what has been proclaimed the 'Anthropocene' era (Davies, 2016). Morton (2017) questions the very concept of 'nature' as something distinct from human society, and uses instead the concept of 'the mesh' to emphasis the interconnectedness of all life, including matter hitherto regarded as 'inanimate'.

Of course, all theorising involves abstraction, and a theory of everything may be beyond our humble ambitions, but the question remains: why focus on the social? Out of all the possible stories, why do we choose to tell this particular story, and what are we missing as a result?

\section{Why focus on childhood?}

We have learned that not only are particular childhoods socially constructed, but that 'childhood' itself is a social construct; although the fact that it is in some form a feature of all societies strongly suggests that there is a non-social basis for this (Qvortrup, 2009). Alanen, Spyrou and others have pointed to the limits of social constructionism as a principal focus for childhood studies. That said, the reality of human biological development does not in itself generate categories, markers or transition points. In this respect we are different from many other species. For example, the transition from caterpillar to butterfly and the differences between the two stages are clearly marked, definite and non-negotiable. The transition from child to adult human, in contrast, is one of infinite, and highly variable, gradation. Modern childhood is often taken to end at 18 years, which is very obviously a social, indeed a legal and policy, construct. One avowed purpose of the social study of childhood is to critique this kind of construction; yet it often appears that we define our field of study using the same artificial markers. It is important to note here, too, that children are different from other social groups with their own field of studies (minority ethnic groups, women, disabled people) in that childhood, however defined, is a temporary phase, not a permanent social grouping. So the question arises, why do we confine our focus of study to this artificially constructed, and temporary, category? 


\section{Why now?}

Third, it is arguable that by taking too narrow a focus of study we also turn a blind eye to several large 'elephants in the room'. By that I mean the existential threats currently posed by climate collapse, poverty and injustice, refuge and displacement, and 'resource wars'.

\section{Climate collapse}

During 2016, the average temperature across global land and ocean surfaces was $1.69^{\circ} \mathrm{F}\left(0.94^{\circ} \mathrm{C}\right)$ above the twentieth-century century average. This was the third year in a row, and the fifth time since 2000, that a new temperature record was set. 1976 was the last time the annual average temperature was cooler than the twentieth-century average. All 16 years of the twenty-first century rank among the 17 warmest years on record (National Centers for Environmental Information, 2016).

The impacts of this warming on the environment, on all forms of plant and animal life, and on human societies, are enormous, unpredictable and potentially catastrophic. The imminent effects in the next few decades may be dwarfed by the longer-term impact of irreversible feedback from events such as melting permafrost. To quote Michael Mann, Distinguished Professor of Atmospheric Science at Penn State University:

The impacts of human-caused climate change are no longer subtle - they are playing out, in real time, before us. They serve as a constant reminder now of how critical it is that we engage in the actions necessary to avert ever-more dangerous and potentially irreversible warming of the planet. (The Guardian, 2016a)

Or, to quote Stefan Rahmstorf of the Potsdam Institute for Climate Impact Research:

We are on a crash course with the Paris targets unless we change course very, very fast. I hope people realise that global warming is not something down the road, but it is here now and it affecting us now. We are catapulting ourselves out of the Holocene, which is the geological epoch that human civilisation has been able to develop in, because of the relatively stable climate. It allowed us to invent agriculture, rather than living as nomads. It allowed a big population growth, it allowed the foundation of cities, all of which required a stable climate. (ibid.)

In terms of human health and wellbeing, climate change was described by the Lancet and Institute for Global Health Commission as 'the biggest global health threat of the $21^{\text {st }}$ century' (Costello et al., 2009).

Amitav Ghosh (2016) argues that fields as disparate as politics, history and literary fiction have failed to engage with the immediacy of the threat of environmental catastrophe, in a phenomenon 
he characterises as 'the great derangement'. We in the field of childhood studies may be open to the same accusation.

\section{Poverty and injustice}

Here, Thomas Pogge (2011) sums up the position clearly:

The bottom half of humanity is living in severe poverty. The collective income of all these people is less than three percent of global household income. The bottom quarter of the human population has only three-quarters of one percent of global household income, whereas the people in the top five percent have nine times the average income... Given the total income and wealth available in the world today, we could easily overcome poverty, which would require raising the share of the bottom half from three to roughly five percent. Unfortunately, the trend is going in the opposite direction. Over the period from 1988 to 2005, the income share of the top five percent has grown by about 3.5 percent of global household income, and the shares of all the other groups have diminished. The greatest relative reduction was in the bottom quarter, which lost about one third of its share of global household income, declining from 1.155 to 0.775 percent, and now is even more marginalized.

The impact of poverty and inequality falls on individuals, families and communities. Children of course are not exempt, and in some respects are especially vulnerable. Unicef (2016) sets out in stark terms the impact of poverty on children: 69 million children will die from mostly preventable causes by 2030, and 167 million will be living in extreme poverty. Nearly half of those deaths will be in sub-Saharan Africa, where at least 247 million children are deprived of what they need to survive and develop. Despite success in some areas of the Millennium Development Goals (now replaced by the Sustainable Development Goals), the number of children who do not attend school has actually increased since 2011.

There is of course a powerful interaction between environmental degradation and global injustice. The poorer parts of the world in general contribute far less to the emissions that have led to global warming, but are tending to feel the first and severest effects. The interaction also extends to two other crises to which we should pay attention: the various refugee emergencies, and the prospect of 'resource wars'.

\section{Refuge and displacement}

According to the UNHCR (2017), a total of 65.6 million people were forcibly displaced worldwide at the end of 2016 - mainly as a result of war, violence and persecution. This was the highest figure ever recorded. Worldwide there were 22.5 million refugees and 10 million stateless people - more than half of them aged under 18 . 
The refugee crisis presents enormous challenges - social and economic challenges in the poorer regions where most refugees remain, and political challenges in the affluent countries where a significant minority attempt to seek refuge and settlement, challenges that intersect with uncertainty about how to respond to increasing numbers of migrant and visiting workers. These issues have already produced destabilising lurches to the right in more than one Western democracy.

\section{Resource wars}

The Iraq war was just the first of this century's 'resource wars', in which powerful countries use force to secure valuable commodities for themselves, according to the UK government's former chief scientific adviser. Sir David King has predicted that with human population growing, natural resources dwindling and seas rising because of climate change, the squeeze on the planet would lead to more conflict.

"Future historians might look back on our particular recent past and see the Iraq war as the first of the conflicts of this kind - the first of the resource wars" (The Guardian, 2016b).

\section{Rearranging deckchairs?}

So we are faced with a collapsing environment, with poverty and inequality on an enormous scale, populations shifting in search of better lives or simply for survival, and the prospect of increasing violent conflict over natural resources. In these circumstances, is it not something of a luxury to be debating the finer points of the social study of childhood? Should we not instead be focusing our efforts on responding to these existential challenges? The severity and urgency of the climate crisis alone seems to suggest that the demand should be "all hands to the pumps", rather than continuing to debate the position of the deckchairs.

\section{The purpose of social enquiry}

An ethical response to these questions comes from a standpoint that social science is fundamentally about making the world better. The aim of critical theory, according to Horkheimer (1982: 244) is 'to liberate human beings from the circumstances that enslave them'. ${ }^{1}$ Responses to this challenge in our own field have included participatory action research (much of it influenced by Paulo Freire (1971), child-led research, and many manifestations of policy-

\footnotetext{
${ }^{1}$ Or to quote a even more distinguished forebear: 'Philosophers have only interpreted the world, in various ways. The point, however, is to change it.' (Marx, 1886)
} 
oriented research. As Prout and James (1990: 9) put it, 'to proclaim a new paradigm of childhood sociology is also to engage in and respond to the process of reconstructing childhood in society'. What is it that we want to understand about children and childhood? For me it can be summed up in questions like these: How do children have real freedom - in the present, in the future? What is the actuality of childhood - locally, globally? How, and when, do children become full members of society? These are critical questions, with an ethical dimension and practical implications. For this reason I am particularly attracted to the most important recent manifestation of critical theory, namely Axel Honneth's $(1995,2014)$ account of recognition and freedom.

Recognition theory can be a tool for investigating children's place in the social order: to examine when, where and how children achieve reciprocal recognition in three distinct modes, (i) as love, (ii) as respect and (iii) as esteem; to look at children as recipients and givers of care and affection, as rights-bearers and rights-respecters, and as members of a community of solidarity based on shared values and reciprocal esteem; to study how different forms of recognition are present in particular social settings - how they are expressed, in what ways they are contested; to ask broader society-level questions about how children are cared for, how their rights are respected, in what ways they are valued as contributing to the general social good; and to study how children recognise each other, and various adults, in relation to the three modes, and what struggles are taking place in those areas, in relation to particular settings or fields, and on a broader societal level (Thomas, 2012).

Honneth's account of recognition is fundamentally an account of freedom and how it is 'actualised'. In his latest work he has moved on to a reconstruction of the institutional conditions of human freedom - 'the social foundations of democratic life', asking what are the values implicit in existing social institutions, how are those expressed in practice, what are the contradictions, and what needs to change in those institutions in order to actualise freedom.

He draws a distinction between negative or legal freedom (the freedom to do what I want), reflexive or moral freedom (the freedom to do what I consider to be good and right) and social freedom (the freedom to act effectively in the world), which is dependent on cooperation with others and on mutual recognition (Honneth, 2014). He thus extends his purview from the intersubjective to relations between people and institutions.

Together with the move to intergenerationality proposed by Leena Alanen and Berry Mayall (2001), this wider focus on institutions offers a way to open up the field and so rise to Jens Qvortrup's (2009) challenge to research childhood as a structural element in all societies, as well as understanding particular formations and experiences. ${ }^{2}$

\footnotetext{
${ }^{2}$ Another example of work that applies innovative and rigorous methods to understanding childhood, in a strong ethical framework, is Priscilla Alderson's recent work with critical realism (Alderson, 2016).
} 


\section{A response to the three questions}

I will now suggest a possible response to the critical questions I posed at the start. This is based on the ethical approach outlined above, and on the following three injunctions: $e$ the social; move into the mainstream; counter the existential threats together.

\section{Expand the social}

I want to argue for the continuing value of a focus on the social, including the political. After all, that is where decisions are made. Every assault on, or human modification of, the earth has been the result of social organisation and collaboration. When people began to farm, they did so in physical relation to the earth, but also in a context of social living where rules were established. It is through social interaction that we guide and constrain each other, that we contest or support each other's ideas, plans and proposals. It is through social interaction that we acquire our sense of who and what we are. That is, of course, worthy of study and critique. But in doing so we should also acknowledge the significance of non-human relationships. If childhood is defined in relation to adulthood, humanity is defined in relation to non-humanity - whether that be other species, the physical environment, or the machines we have created. It is no longer sufficient to write as if social actors operate in isolation from the material world - as Alan Prout has argued for some time (Prout 2005), and as Spyros Spyrou argues in this publication and in his recent book (Spyrou 2018) - or as if social interaction is a uniquely human practice, when other beings also engage in social interaction, with each other and with us. However, 'decentering' (wholly or partially) the human does not necessarily imply moving away from, or turning our back on, the social; rather, it can mean expanding our notion of the social to include these other elements. This probably means granting them some sort of agency - but, I would argue, a different sort of agency in the case of humans and animals than for machines and other objects. (See Oswell, 2013, and more recently Spyrou, 2018, for a fuller discussion of the complex questions around agency.)

\section{Move into the mainstream}

The future of childhood studies must, if the work of scholarship is to have lasting value, include a decisive move out of its present enclave and into the mainstream of social and political inquiry. Mainstream social and political theory still fails to recognise children as social actors; the experience of running a sociology of childhood network in a large international association of sociologists, and feeling sometimes like part of a disregarded sect or cult, has been a painful reminder of that. Speier's perception from forty years ago still holds true: 'The intellectual and analytic position of sociologists is essentially ideological in the sense that they have used an 
adult notion of what children are and what they ought to be that is like that of the laymen in the culture' (1976: 170).

Childhood is a relational concept. This means that when we learn about childhood we also learn about adulthood. When we study children we study people - people with gender, with ethnic origins, with cultural backgrounds, and with specific constellations of abilities and disabilities. When we study social relations and social interaction involving children, we do not isolate children from their wider social context, and what we learn has a wider application; especially if we have learned not to essentialise but to think in terms of 'people occupying the social space currently defined as childhood'. And of course, as others, including Jens Qvortrup, have pointed out, we have to move on from a preoccupation with agency and 'voice' to look systematically at childhood in social structure.

Spyros Spyrou, here and elsewhere $(2017 ; 2018)$, argues for a 'decentering' of childhood as a category, combined with a stronger orientation to relationality. That makes much sense as far as childhood studies as a distinct field is concerned: just as women's studies realised that the study of patriarchy was absolutely central to its purpose as a field, so childhood studies makes little sense without an understanding of adult power in all its complexity and contradiction. However, there is also a need for a simultaneous recentring of children and childhood in social and political theory. Theoretical blindness to the actual position of children may serve to reinforce the practical exclusion of children from many aspects of social, political and economic life, and part of our responsibility as scholars of childhood studies is to address those gaps in understanding. This is not to say that it is not happening at all - there have been some distinguished publications in mainstream journals by scholars of childhood (eg James 2010, Moran-Ellis 2010) - but more is needed.

\section{Work together to counter the existential threats}

Finally, the existential threats facing humanity, and other inhabitants of this planet, have to be addressed in a way that includes children as social and political actors with an essential contribution to make to the process and a major stake in the outcomes. It is clear that the challenge of dealing with the overwhelming threats to our environment now and in the future requires a new kind of politics and new kinds of social action. The demand must be based on the illegitimacy of power held by a few and on bringing in new voices and new actors - including people most directly affected by abuses of the environment such as those in the far north or in low-lying Pacific islands. This applies in particular to children - those who are children now and who have so much more at stake than older people, and those who will be children in the future and who will be required to make sense of the mess that is left. The understandings that we develop, in our science, of the constraints on children's freedom, of their potential for autonomous and collective action, can contribute to the opening up of public debate on these 
issues. Children often have a clearer understanding of the threats, and of the ethical priorities, than many adults. Their world view often embraces the very local and the global. When the boat needs bailing out, all hands are needed.

\section{Conclusion}

Our work to examine 'childhood' critically, to understand how children's lives are constructed and what is children's place in the world, to the extent that this is informed by an ethical imperative and principle of respect for children as persons, and to the extent that it is influential in the wider society, can contribute to expanding the conditions of freedom for those occupying the temporary social position designated as childhood, and promoting their fuller participation in public decision-making and social action. If we accept Iris Marion Young's contention that democracy is 'a means of collective problem-solving which depends for its legitimacy and wisdom on the expression and criticism of the diverse opinions of all the members of the society' (Young 2000: 6), then we begin to see how a project to understand, recognise and augment children's role as members of a society and a polity can also be a contribution to tackling some of the existential threats currently faced by us all; and our work need not be a waste of time.

\section{References}

Alanen, Leena and Mayall, Berry (eds) (2001) Conceptualizing Child-Adult Relations. London: Routledge Falmer.

Alderson, Priscilla (2016) The Politics of Childhoods Real and Imagined: Practical Application of Critical Realism and Childhood Studies. London: Routledge.

Costello, Anthony and 27 others (2009) 'Managing the health effects of climate change', Lancet 373 (Issue 9676), 1693-1733.

Davies, Jeremy (2016) The Birth of the Anthropocene. University of California Press.

DeLanda, Manuel (2006) A New Philosophy of Society: Assemblage Theory and Social Complexity. New York: Bloomsbury Academic.

Freire, Paulo (1971) Pedagogy of the Oppressed. Harmondsworth: Penguin.

Ghosh, Amitav (2016) The Great Derangement: Climate Change and the Unthinkable. University of Chicago Press.

Honneth, Axel (1995) The Struggle for Recognition: The Moral Grammar of Social Conflicts. Cambridge: Polity.

Honneth, Axel (2014) Freedom's Right: The Social Foundations of Democratic Life. Cambridge: Polity. 
Horkheimer, Max (1982) eitical Theory. New York: Seabury Press.

James, Allison (2010) 'To be (come) or not to be (come): understanding children's citizenship', Annals of American Academy of Political and Social Science 633(1), 167-179.

James, Allison, Jenks, Chris and Prout, Alan (1998) Theorizing Childhood. Cambridge: Polity.

Moran-Ellis, Jo (2010) 'Reflections on the Sociology of Childhood in the UK', Current Sociology 58(2), 186-205.

Latour, Bruno (2005) Reassembling the Social: An Introduction to Actor-Network Theory. Oxford University Press.

Marx, Karl (1886) 'Theses on Feuerbach' in Engels, F., Ludwig Feuerbach and the End of Classical German Philosophy. Stuttgart: Die Neue Zeit.

Morton, Timothy (2017) Humankind: Solidarity with Nonhuman People. London: Verso Books. National Centers for Environmental Information (2016). Global Summary Information - Annual 2016. https://www.ncdc.noaa.gov/sotc/global/201613 (accessed 15/06/2018).

Oswell, David (2013) The Agency Of Children: From Family to Global Human Rights. Cambridge University Press.

Pogge, Thomas (2011) 'Thomas Pogge on the Past, Present and Future of Global Poverty' (interview by Keane Bhatt). Truthout. http://www.truth-out.org/news/item/792:thomas-poggeon-the-past-present-and-future-of-global-poverty (accessed 15/06/2018).

Prout, Alan (2005) The Future of Childhood. London: Routledge.

Prout, Alan and James, Allison (1990) 'A new paradigm for the sociology of childhood? Provenance, promise and problems' in James, A. and Prout, A. (eds) Constructing and Reconstructing Childhood: Contemporary issues in the sociological study of childhood. Basingstoke: Falmer Press.

Qvortrup, Jens (2009) 'Childhood as a structural form' in Qvortrup, J., Corsaro, W. and Honig, M. (eds) The Palgrave Handbook of Childhood Studies. Basingstoke: Palgrave Macmillan.

Speier, Matthew (1976) 'The adult ideological viewpoint in studies of childhood' in Skolnick, A. (ed.) Rethinking Childhood: perspectives on development and society. Boston: Little, Brown.

Spyrou, Spyros (2017) ‘Time to decenter childhood?' Editorial in Childhood 24(4), 433-437. Spyrou, Spyros (2018) Disclosing Childhoods: Research and Knowledge Production for a Critical Childhood Studies. Basingstoke: Palgrave Macmillan.

Taylor, Affrica and Pacini-Ketchabaw, Veronica (2015) 'Learning with children, ants, and worms in the Anthropocene: towards a common world pedagogy of multispecies vulnerability', Pedagogy, Culture \& Society 23(4), 507-529. 
The Guardian (2016a) 'Shattered records show climate change is an emergency today, scientists warn' by Damian Carrington (https://www.theguardian.com/environment/2016/jun/17/shatteredrecords-climate-change-emergency-today-scientists-warn, accessed 06/02/2017).

The Guardian (2016b) 'David King: Iraq was the first 'resource war' of the century' by James Randerson (https://www.theguardian.com/environment/2009/feb/12/king-iraq-resources-war, accessed 16/06/2018).

Thomas, Nigel (2012) 'Love, rights and solidarity: Studying children's participation using Honneth's theory of recognition', Childhood 19(4), 453-466.

UNHCR (2017) Global Trends 2016 (http://www.unhcr.org/globaltrends2016/, accessed 16/06/2018).

Unicef (2016) The State of the World's Children (http://www.unicef.org/sowc2016/, accessed 06/02/2017).

Woodhead, Martin (2009) 'Child Development and the Development of Childhood' in Qvortrup, J., Corsaro, W. and Honig, M. (eds) The Palgrave Handbook of Childhood Studies. Palgrave Macmillan.

Young, Iris Marion (2000) Inclusion and Democracy, New York: Oxford University Press. 